ISSN 1392-3196 / e-ISSN 2335-8947

Zemdirbyste-Agriculture, vol. 102, No. 3 (2015), p. 319-324

DOI 10.13080/z-a.2015.102.041

\title{
The influence of compound feed enrichment with rapeseed and linseed cake on the meat characteristics and fatty acids composition of beef bulls
}

\author{
Gintarė BALTRUKONIENE, Virginijus UCHOCKIS, Gintautas Juozas ŠVIRMICKAS \\ Institute of Animal Science, Lithuanian University of Health Sciences \\ R. Žebenkos 12, Baisogala, Radviliškis distr., Lithuania \\ E-mail: gintare.baltrukoniene@gmail.com
}

\begin{abstract}
The trial was conducted with Lithuanian Black-and-White bulls of 10 to 16 months age. The bulls were divided into analogous groups according to their origin, age and weight. During the trial the bulls in both groups were offered the same amount of maize silage, clover-oat-pea mixture silage and compound feed, the only difference being the composition of compound feeds. The aim of the study was to investigate the effects of compound feeds containing rapeseed and linseed cake and different amounts of n- 6 and n-3 fatty acids on the fatty acid pattern in the longest muscle of the back (Musculus longissimus dorsi) meat of Lithuanian Black-and-White fattening bulls. Fatty acids n-6:n-3 ratio in rapeseed cake was 2.75 , and that in linseed cake 0.25 . More favourable ratio in linseed cake was determined by higher content of linolenic acid (C18:3n-3). Different feeding of bulls as regards rapeseed and linseed cake, fatty acid content and n-6:n-3 ratio had no significant influence on the weight of bulls prior to slaughter, carcass weight and yield, lean meat content and fatness grades. According to the SEUROP carcass classification system, the carcasses in both groups of bulls met the requirements for lean meat content $\mathrm{O}$ and fatness 2 grades. The study indicated that ground beef contained $49.93 \%$ higher $(P<0.05)$ content of linolenic acid (C18:3n-3) when the animals were fed compound feed with linseed cake and, therefore, higher n-6:n-3 ratio was influenced by a higher content of this acid in the feed. The study also indicated that total $\mathrm{n}-3$ fatty acid content was 1.3 times greater and n- 6 to n-3 fatty acid ratio was found 1.5 times lower $(P<0.05)$ in $M$. longissimus dorsi when feeding bulls linseed cake.
\end{abstract}

Key words: carcasses, cattle carcasses, fatty acid, linseed cake, rapeseed cake.

\section{Introduction}

Oilseed rape growing in Europe has recently significantly increased. Rapeseed growing is important in oil and biofuel production and especially for animal feeding. Rapeseed processing into oil produces a by-product - rapeseed cake (Kaldmäe et al., 2006). Rapeseed cake contains protein, is rich in minerals, vitamins (especially B group) and is characterized by high energy value due to high fat content (Sarwar et al., 2013). However, the use of rapeseed cake in the rations of lactating cows and fattening bulls is restricted by the amounts of glucosinolates, fitinic acid, tannins and sinapicacid because these anti-nutritional compounds could have a negative effect on protein digestibility and worsen the sensory qualities of the feed. Various methods of rapeseed breeding and feed production technologies are applied in order to reduce the amounts of these antinutritional compounds. Despite the above anti-nutritional factors, rapeseed is characterized by a favourable fatty acid composition, quite a good ratio of n-6 to n-3 fatty acids, comparatively high content of oleic acid, which reduces blood cholesterol, and high energy value of the feed (Rule et al., 1989; Komprda et al., 2002).
Currently, the use of linseed cake has also increased because more food products are being made containing components beneficial to human health. Linseed cake contains about $30 \%$ protein and a high content $\left(23.59 \mathrm{~g} \mathrm{~kg}^{-1}\right)$ of polyunsaturated fatty acids. The content of linoleic acid (C18:2n-6) in linseed cake amounts to even $5.52 \mathrm{~g} \mathrm{~kg}^{-1}$, therefore, the use of this feedstuff is rapidly increasing with the aim of improving $\mathrm{n}-6: \mathrm{n}-3$ ratio in animal products as well as their nutritive value and quality. However, linseed cake contains cyanogenic glucosides that might induce poisoning. Despite the fact that the digestibility of linseed protein is high, the content of lysine is insufficient. Furthermore, linseed in the richest oilseed source of linolenic acid (Ebrahimi et al., 2013).

Linseed is a good source of linoleic acid (C18:2n-6) and especially linolenic acid (C18:3n-3), n-6 and n-3 polyunsaturated fatty acids (PUFA), which are essential because mammals, including humans, cannot endogenously synthesize them and must adopt endogenously from dietary sources. In spite of its high nutritive value, linseed has not been effectively exploited in animal feeding (Ebrahimi et al., 2013). 
Over the past two centuries, human intake of n-6 and n-3 fatty acids has changed in the wrong direction. The ratio of these acids increased from 2-4 to $10-30$ and more. Social studies established that there is a steadily increasing consumer interest in foods with these fatty acids (Vanhala et al., 2012). n-3 fatty acids, monounsaturated fat, polyunsaturated fat and unsaturated fat have important roles in the diet. Some unsaturated fat such as n-3 fatty acids are sometimes consumed at a level lower than recommended, accredited by Commission Regulation (EC) No. 1924/2006 amending Commission Regulation (EU) No. 116/2010.

Lately, the number of people concerned about maintaining a healthy diet has increased. The consumption of fat has reduced as it has been related to human cardiovascular diseases, obesity and cancer (JiménezColmenero et al., 2001). However, fat represents between $25-30 \%$ of the total body weight of an individual adult and perform important functions in the body (Hegarty, 1995). Thus, fat must be present in the diet, especially some polyunsaturated fatty acids, which, if not consumed in the necessary amount, may alter the perfect functioning of the body, since they cannot be synthesised by it. The bovine meat fat presents approximately $48 \%$ of saturated fat and $52 \%$ of unsaturated fat (Jiménez-Colmenero et al., 2001). Since saturated fatty acids are not essential and have been associated with health problems (JiménezColmenero et al., 2001; Sailas, Spener, 2009), bovine meat consumption may be prejudiced due to the search for healthier diets. According to this, many studies have been conducted to decrease the proportion of saturated fatty acids and increase the polyunsaturated fatty acids of the meat. Dietary manipulation of muscle and adipose tissue was proven possible and the potential to enrich ruminant tissues with n-3 PUFA has been demonstrated (Marmer et al., 1984; Scollan et al., 2001; 2006). One of the studies (Warren et al., 2008) examined the effects of breed and diet on the fatty acid composition of beef M. longissimus dorsi. The breeds tested were Aberdeen cross and Holstein-Friesian, fed on a concentrate or grass silage, rich in n-6 and n-3 PUFA, respectively. The increase in the levels of n-3 series fatty acids with silage feeding resulted in beneficially low n-6:n-3 ratios in muscle in all age groups, approximately 1.2 compared with 12.0 in the concentrate diet (Warren et al., 2008). The study conducted by Do Prado et al. (2003) showed that steers fed on only pasture forages could result in a fat deposition with a higher amount of polyunsaturated fatty acids, which would lead to a healthier aliment, with lower saturated fat contents. The main objective when growing animals for meat is to keep a beneficial $n-6: n-3$ ratio and at the same time increase the amount of polyunsaturated fatty acids (Wood et al., 2008). Drouillard et al. (2004) and Nuernberg et al. (2005) indicated that the content of n-3 fatty acid was significantly higher in the meat from cattle fed linseed supplemented diets.

It is advised by health specialists to reduce the amount of saturated fatty acids and increase the amount of polyunsaturated fatty acids in human diets. In order to change fatty acid composition in meat, milk and eggs, and to make these products healthier for human consumption, more attention should be paid to the feedstuffs and ingredients of the animal diet (French et al., 2000; Scollan et al., 2001; 2006; Dewhurst et al., 2003; Nuernberg et al., 2005).
The purpose of our study was to investigate the compound feed with either rapeseed or linseed cake used for fattening bulls with different contents of n-6 and n-3 fatty acids in bovine $M$. longissimus dorsi and ground meat.

\section{Material and methods}

A trial with Lithuanian black-and-white bulls was carried out in 2010. Twelve-month-old healthy bulls were divided into analogous groups according to their origin, age and weight. The bulls were kept tethered, automatically watered and housed under the same conditions. During the trial, the bulls of both groups were given the same amount of maize silage, clover-oat-pea mixture silage and compound feed. The only difference was the composition of the compound feed. Silaged feeds were given per group, while compound feed was offered individually. The bulls were fed twice daily - in the morning maize silage ad libitum and $2 \mathrm{~kg}$ compound feed was offered, while in the evening the bulls were fed clover-oat-pea mixture silage ad libitum and $2 \mathrm{~kg}$ compound feed. The composition of compound feed with rapeseed cake was crushed barley grain $-33 \%$, crushed triticale $-33 \%$, crushed oats $-17 \%$, rapeseed cake $-15 \%$, mineral-vitamin supplement $-2 \%$ (composition of Vita-Prem G-24 premix: vitamin A - 18 IU (international units), vitamin D - 3.6 IU, vitamin E $90 \mathrm{mg}$, manganese $(\mathrm{Mn})-150 \mathrm{mg}$, zinc $(\mathrm{Zn})-150 \mathrm{mg}$, cuprum $(\mathrm{Cu})-36 \mathrm{mg}$, iodine (I) $-4.2 \mathrm{mg}$, selenium (Se) $-0.75 \mathrm{mg}$, cobalt $(\mathrm{Co})-1.5 \mathrm{mg})$. The composition of the compound feed for the second group was analogous, except that rapeseed cake was replaced by $15 \%$ linseed cake. At the end of the trial, six bulls from each group were slaughtered. Samples of M. longissimus dorsi, 0.5 $\mathrm{kg}$, and ground meat, $1 \mathrm{~kg}$, were taken from left side carcasses. Relative fatty acid contents were analyzed in M. longissimus dorsi and ground meat.

Feed samples were collected to determine the chemical composition and fatty acid content. The feeds were analyzed for dry matter, crude protein, crude fat, crude fibre, crude ash (AOAC, 1990); calcium by the method of atomic absorption, phosphorus by the photometric method using molibdovanadate reagent (AOAC, 1990). The energy value of the feeds for cattle was calculated according to Jeroch et al. (1999).

The extraction of lipids for fatty acid analysis was performed with chloroform/methanol $(2: 1 \mathrm{v} / \mathrm{v})$ as described by Folch et al. (1957). Fatty acid methyl esters were prepared using the procedure of Christopherson and Glass (1969). The fatty acid methyl esters were analysed using a gas-liquid chromatograph "GC-2010 Shimadzu" (Japan) fitted with a flame ionization detector. The separation of methyl esters of fatty acids was effected on a capillary column "Rt-2560 Restek" (USA), $100 \mathrm{~m} \times$ $0.25 \mathrm{~mm} \times 0.25 \mu \mathrm{m}$. The relative proportion of each fatty acid was expressed at the relative percentage of the sum of the total fatty acids. Lipid quality indices - atherogenic index (AI) and thrombogenic index (TI), were calculated according to Ulbricht and Southgate (1991):

$$
\mathrm{AI}=[\mathrm{C} 12: 0+(4 \times \mathrm{C} 14: 0)+\mathrm{C} 16: 0] /[\mathrm{n}-6 \mathrm{PUFA}
$$

+ n-3 PUFA + MUFA];

$$
\mathrm{TI}=[\mathrm{C} 14: 0+\mathrm{C} 16: 0+\mathrm{C} 18: 0] /[(0.5 \times \mathrm{MUFA})+
$$

$(0.5 \times$ n-6 PUFA $)+(3 \times$ n-3PUFA $)$ n-3/n-6+PUFA $]$.

The data were processed using STATISTICA for Windows, version 7 . The differences were significant at $P<0.05$. 


\section{Results and discussion}

Cake composition. The analysis of the chemical composition of rapeseed and linseed cake indicated that rapeseed cake contained by $5.54 \%$ more crude protein and $43.63 \%$ calcium. Linseed cake contained more dry matter $-2.0 \%$, crude fat $-87.6 \%$, crude fibre $-42.7 \%$ and phosphorus $-25.65 \%$. The energy value of linseed cake was $10 \%$ higher than that of rapeseed cake (Table 1).

Table 1. Chemical composition and energy value of rapeseed and linseed cake

\begin{tabular}{lcc}
\hline \multicolumn{1}{c}{ Item } & $\begin{array}{c}\text { Rapeseed } \\
\text { cake }\end{array}$ & $\begin{array}{c}\text { Linseed } \\
\text { cake }\end{array}$ \\
\hline & Analysis, 1 kg feed & \\
\hline Dry matter g kg-1 & 946.0 & 965.0 \\
Metabolizable energy MJ/AE & 12.53 & 13.79 \\
Crude protein g kg-1 & 307 & 290 \\
Crude fat g kg-1 & 121 & 227 \\
Crude fibre g kg-1 & 159 & 227 \\
Calcium g kg-1 & 5.41 & 3.05 \\
Phosphorus g kg-1 & 7.60 & 9.55 \\
\hline
\end{tabular}

Fatty acid content, $\%$ of total fatty acids content

\begin{tabular}{lcc}
\hline Palmitic (C16:0) & 5.42 & 5.83 \\
Stearic (C18:0) & 1.32 & 2.64 \\
Oleic (C18:1n-9) & 57.82 & 18.11 \\
Linoleic (C18:2n-6) & 23.80 & 14.60 \\
Linolenic (C18:3n-3) & 8.66 & 58.59 \\
Arachidic (C20:0) & 0.46 & 0.10 \\
Eicosenoic (C20:1n-9) & 1.07 & 0.13 \\
Behenic (C22:0) & 0.29 & nd \\
Erucic (C22:1) & 0.29 & nd \\
Decosenoic (C22:2) & 0.46 & nd \\
Total SFA & 7.49 & 8.57 \\
Total MUFA & 59.59 & 18.24 \\
Total PUFA & 32.92 & 73.19 \\
P:S & 4.40 & 8.54 \\
Total n-6 & 23.80 & 14.60 \\
Total n-3 & 8.66 & 58.59 \\
n-6:n-3 & 2.75 & 0.25 \\
\hline SFA
\end{tabular}

SFA - sum of saturated fatty acids, MUFA - sum of monounsaturated fatty acids, PUFA - sum of polyunsaturated fatty acids; $P: S$ - ratio of PUFA to SFA; $n-6$ - sum of $n-6$ PUFA, n-3 - sum of n-3 PUFA, fatty acids n-6:n-3 ratio; nd not detected

Rapeseed cake was analyzed for per cent ratio of fatty acids. Oleic acid (C18:1n-9) accounted for $57.82 \%$, linoleic $(\mathrm{C} 18: 2 \mathrm{n}-6)$ - for $23.80 \%$, linolenic $(\mathrm{C} 18: 3 \mathrm{n}-3)$ - for $8.66 \%$ and palmitic $(\mathrm{C} 16: 0)$ - for $5.42 \%$. The percentage of linolenic $(\mathrm{C} 18: 3 n-3)$, oleic $(\mathrm{C} 18: 1 \mathrm{n}-9)$ and linoleic (C18:2n-6) acids in linseed cake was 58.89, 18.11 and $14.60 \%$, respectively. Low amounts of behenic (C22:0), erucic (C22:1) and decosenoic (C22:2) acids were found in rapeseed cake, whereas linseed cake was devoid of the above-mentioned acids. Komprda et al. (2002) found $55.4 \%$ oleic (C18:1n-9), 20.6\% linoleic $(\mathrm{C} 18: 2 \mathrm{n}-6)$ and $6.1 \%$ linolenic $(\mathrm{C} 18: 3 \mathrm{n}-3)$ acids in rapeseed cake. High content of oleic acid predetermines high content of MUFA in rapeseed cake. In linseed cake the content of linoleic $(\mathrm{C} 18: 2 \mathrm{n}-6)$ acid accounts for $58.59 \%$ of the total amount of fatty acids, therefore, the ratio of PUFA in linseed cake is by 2.2 times higher than that in rapeseed cake. The quantitative ratio of $n-6$ and $\mathrm{n}-3$ fatty acids in rapeseed cake is 11 times higher than that in linseed cake (Table 1).
Carcass and meat quality data. At the end of the trial, the bulls of both groups were slaughtered. The finish weight of the bulls fed compound feed with rapeseed cake was $427.5 \mathrm{~kg}$, and that of bulls fed linseed cake was $435.0 \mathrm{~kg}$, or $1.75 \%$ higher. However, the carcass weight was higher in rapeseed cake group $213.2 \mathrm{~kg}$, whereas in linseed cake group it was $212.2 \mathrm{~kg}$, or $0.5 \%$ lower. Consequently, the dressing percentage in linseed cake group was $1.06 \%$ lower. Bull feeding with compound feeds containing different cake, fatty acid contents and omega 6:3 ratios had no significant effects on the finish weight, carcass weight and dressing percentage (Table 2).

Table 2. Control slaughter data of bulls

\begin{tabular}{lcc}
\hline \multirow{2}{*}{\multicolumn{1}{c}{ Item }} & \multicolumn{2}{c}{ Groups } \\
\cline { 2 - 3 } & rapeseed cake & linseed cake \\
\hline Finish weight kg & $427.5 \pm 6.76$ & $435.0 \pm 4.69$ \\
Carcass weight kg & $213.2 \pm 4.66$ & $212.2 \pm 3.06$ \\
Dressing percentage \% & $49.87 \pm 0.62$ & $48.81 \pm 0.64$ \\
Fleshiness score & $\mathrm{O}$ & $\mathrm{O}$ \\
Fatness score & 2 & 2 \\
\hline
\end{tabular}

According to SEUROP carcass classification, the carcasses of both bull groups met the requirements for lean meat content grade $\mathrm{O}$ and fatness grade 2 (fatness grade 1 means carcass the lowest fat content and grade 5 - the highest fat content) (Nogalski et al., 2012). The fatness of carcasses was sufficient. Bendikas et al. (2008) indicated that the above distribution by lean meat content and fatness grades is characteristic of dairy bulls grown for meat.

Fatty acid compositions. The beneficial effects of PUFA depend on the ratio of n-6 PUFA to n-3 PUFA; it is generally accepted that the ideal proportion of $n-6$ to $\mathrm{n}-3$ is around $4: 1$. The beneficial effect is obtained with a daily intake of $2 \mathrm{~g}$ of linolenic acid (C18:3n-3) and a daily intake of $10 \mathrm{~g}$ of linoleic acid (C18:2n-6) n-6 (Commission Regulation (EU) No. 376/2010).

The analysis of the fatty acid content in M. longissimus dorsi indicated that higher fatty acid content was found in the rape cake group for stearic (C18:0) $2.66 \%(P<0.05)$ and octadecadienoic $(\mathrm{C} 18: 2 \mathrm{n}-6) 0.61 \%$ acids (Table 3 ). However, in the linseed cake group higher fatty acid content was found for palmitic (C16:0) 2.1\% $(P<0.05)$, hexadecenoic (C16:1n-9) $0.66 \%(P<0.05)$, octadecenoic (C18:1n-9) 0.46\%, linolenic (C18:3n-3) $0.31 \%(P<0.05)$ and eicosapentaenoic $(\mathrm{C} 20: 5 \mathrm{n}-3) 0.12$ $(P<0.05)$ acids. There were no significant differences for the other fatty acids observed or they were not detected.

To conclude, $0.55 \%$ higher total sum of saturated fatty acids content was found when bulls had been fed compound feeds containing rapeseed cake vs. linseed cake. Conversely, $0.96 \%$ higher total MUFA content was determined when feeding linseed cake $v s$ rapeseed cake. Insignificantly, $0.38 \%$ higher total PUFA content was found when feeding rapeseed cake in comparison with linseed cake. Total n-3 PUFA content was $0.44 \%(P<$ $0.05)$ higher when bulls were offered linseed cake than rapeseed cake. The recommended ratio is lower than 4 . However, domestic animals produce an undesirably high n-6:n-3 ratio in meat (Wood et al., 2003). Other authors Do Prado et al. (2003) and Nuernberg et al. (2005) indicate fatty acid composition differences between the breeds; however, there are few data on compound feeds 
Table 3. Fatty acids composition of Musculus longissimus dorsi

\begin{tabular}{lcc}
\hline \multicolumn{1}{c}{ Item } & $\begin{array}{c}\text { Diet with } \\
\text { rapeseed cake }\end{array}$ & $\begin{array}{c}\text { Diet with } \\
\text { linseed cake }\end{array}$ \\
\hline \multicolumn{2}{c}{ Fatty acid content, \% of total fatty acid content } \\
\hline Palmitic (C16:0) & $24.86 \pm 1.81$ & $26.96 \pm 0.18^{*}$ \\
Hexadecenoic (C16:1n-9) & $3.77 \pm 0.44$ & $4.43 \pm 0.26^{*}$ \\
Stearic (C18:0) & $15.55 \pm 1.50$ & $12.89 \pm 0.50^{*}$ \\
Octadecenoic (C18:1n-9) & $40.04 \pm 1.24$ & $40.50 \pm 1.07$ \\
Linoleic (C18:2n-6) & $4.15 \pm 0.80$ & $3.54 \pm 0.41$ \\
Linolenic (C18:3n-3) & $0.74 \pm 0.06$ & $1.05 \pm 0.09^{*}$ \\
Eicosapentaenoic (C20:5n-3) & $0.12 \pm 0.09$ & $0.24 \pm 0.09^{*}$ \\
Docosapentaenoic (C22:5n-3) & $0.29 \pm 0.05$ & $0.31 \pm 0.02$ \\
Total SFA & $43.38 \pm 1.10$ & $42.83 \pm 0.45$ \\
Total MUFA & $48.62 \pm 1.64$ & $49.58 \pm 0.64$ \\
Total PUFA & $7.17 \pm 1.15$ & $6.79 \pm 0.57$ \\
P:S & $0.17 \pm 0.03$ & $0.16 \pm 0.01$ \\
Total n-6 & $5.76 \pm 1.01$ & $4.98 \pm 0.45$ \\
Total n-3 & $1.36 \pm 0.23$ & $1.80 \pm 0.16^{*}$ \\
n-6:n-3 & $4.23 \pm 0.31$ & $2.77 \pm 0.20^{*}$ \\
AI & $0.58 \pm 0.06$ & $0.62 \pm 0.01$ \\
TI & $1.34 \pm 0.07$ & $1.27 \pm 0.02$ \\
Trans-isomers & $2.24 \pm 0.25$ & $2.10 \pm 0.42$ \\
\hline SFA - sum
\end{tabular}

SFA - sum of saturated fatty acids, MUFA - sum of monounsaturated fatty acids, PUFA - sum of polyunsaturated fatty acids; P:S - ratio of PUFA to SFA; $n-6$ - sum of n-6 PUFA, $n-3$ - sum of $n-3$ PUFA, fatty acids $n-6: n-3$ ratio; AI atherogenic index, TI - thrombogenic index; $*-P<0.05$

for cattle with different amounts of n-3 and n-6 fatty acids. Herdmann et al. (2010) observed that cattle diet supplementation with feeds containing linolenic acid $(\mathrm{C} 18: 3 n-3)$ resulted in significantly higher content of n-3 fatty acids and lower content of n-6 fatty acids in bovine meat. This is in agreement with the findings of Scollan et al. (2006), Wood et al. (2008) and Herdmann et al. (2010). In our study, n-6:n-3 ratio in M. longissimus dorsi was about $30 \%(P<0.05)$ higher when bulls were offered linseed cake (Table 3 ). The atherogenic (AI) and thrombogenic (TI) indices did not differ in between.

The analysis of the fatty acid content in ground bovine meat indicated that higher fatty acid content had been found in the meat of bulls fed rapeseed cake, i.e. myristic (C14:0) by $0.12 \%$, palmitic $(\mathrm{C} 16: 0)$ by $0.48 \%$, hexadecenoic $(\mathrm{C} 16: 1 \mathrm{n}-9)$ by $0.23 \%$ and octadecenoic (C18:1n-9) by $1.67 \%$. However, feeding with linseed cake resulted in higher contents of stearic $(\mathrm{C} 18: 0)$ by $0.49 \%$, vaccenic $(\mathrm{C} 18: 1 \mathrm{n}-7)$ by $0.11 \%$, linoleic $(\mathrm{C} 18: 2 \mathrm{n}-6)$ even by $1.02 \%$, linolenic $(\mathrm{C} 18: 3 \mathrm{n}-3)$ by $0.54 \%(P<0.05)$ and arachidonic $(\mathrm{C} 20: 4 \mathrm{n}-6)$ by $0.16 \%$ acids. There were no significant differences observed for the other fatty acids or they remained unidentified (Table 4).

Clinical studies have shown that there is a lower probability of heart diseases when the content of saturated and unsaturated fatty acids is changed, especially that of n-3 fatty acid content, in comparison with simply lower consumption of total fats (Sanders, 2003).

In conclusion, $0.28 \%$ higher content of sum of saturated fatty acids was determined when feeding bulls with rapeseed cake compared to linseed. Herdmann et al. (2010) observed that cattle diet supplementation with feeds containing linolenic acid (C18:3n-3) resulted in significantly higher content of n-3 fatty acids and lower content of $n-6$ fatty acids in bovine meat. The total MUFA content was determined to be $1.73 \%$ higher when bulls were fed compound feed containing rapeseed cake compared to linseed cake. The total PUFA content was determined to be $1.8 \%$ higher when bulls were given linseed cake in comparison with rapeseed cake. The total n-3 fatty acid content was $0.73 \%(P<0.05)$ higher when feeding linseed cake $v s$ rapeseed cake. The results from the trial indicated that $n-6: n-3$ ratio was lower when bulls had been fed compound feed containing linseed cake.

Table 4. Fatty acid composition of ground bovine meat

\begin{tabular}{lcc}
\hline \multicolumn{1}{c}{ Item } & Rapeseed cake & Linseed cake \\
\hline \multicolumn{2}{c}{ Fatty acid content, \% of total fatty acid content } \\
\hline Myristic (C14:0) & $1.66 \pm 0.38$ & $1.54 \pm 0.05$ \\
Myristoleic (C14:1) & $0.35 \pm 0.14$ & $0.32 \pm 0.06$ \\
Pentadecanoic (C15:0) & $0.69 \pm 0.21$ & $0.52 \pm 0.11$ \\
Palmitic (C16:0) & $23.17 \pm 2.07$ & $22.69 \pm 0.79$ \\
Hexadecenoic (C16:1n-9) & $3.79 \pm 0.37$ & $3.56 \pm 0.27$ \\
Hexadecadienoic (C16:2n-4) & $0.29 \pm 0.29$ & $0.27 \pm 0.15$ \\
Margaric (C17:0) & $0.75 \pm 0.06$ & $0.75 \pm 0.06$ \\
Heptadecenoic (C17:1) & $0.71 \pm 0.06$ & $0.67 \pm 0.03$ \\
Stearic (C18:0) & $13.38 \pm 0.66$ & $13.87 \pm 0.52$ \\
Octadecenoic (C18:1n-9) & $39.92 \pm 2.26$ & $38.25 \pm 2.35$ \\
Vaccenic (C18:1n-7) & $1.73 \pm 0.30$ & $1.84 \pm 0.19$ \\
Linoleic (C18:2n-6) & $5.41 \pm 1.98$ & $6.43 \pm 0.77$ \\
Linolenic (C18:3n-3) & $0.87 \pm 0.12$ & $1.41 \pm 0.31 *$ \\
Eicosatrienoic (C20:3n-3) & $0.35 \pm 0.15$ & $0.36 \pm 0.04$ \\
Arachidonic (C20:4n-6) & $2.17 \pm 1.06$ & $2.33 \pm 0.45$ \\
Eicosapentaenoic (C20:5n-3) & $0.25 \pm 0.13$ & $0.33 \pm 0.07$ \\
Docosatetraenoic (C22:4n-6) & $0.13 \pm 0.15$ & nd \\
Docosapentaenoic (C22:5n-3) & $0.55 \pm 0.24$ & $0.65 \pm 0.12$ \\
Total SFA & $39.65 \pm 2.85$ & $39.37 \pm 1.06$ \\
Total MUFA & $48.64 \pm 2.17$ & $46.91 \pm 2.46$ \\
Total PUFA & $10.51 \pm 3.93$ & $12.31 \pm 1.76$ \\
P:S & $0.27 \pm 0.11$ & $0.31 \pm 0.04$ \\
Total n-6 & $8.20 \pm 3.14$ & $9.28 \pm 1.20$ \\
Total n-3 & $2.02 \pm 0.58$ & $2.75 \pm 0.46$ \\
n-6:n-3 & $3.98 \pm 0.55$ & $3.41 \pm 0.34 *$ \\
AI & $0.51 \pm 0.08$ & $0.49 \pm 0.03$ \\
TI Trans-isomer & $1.11 \pm 0.17$ & $1.04 \pm 0.05$ \\
SFA sum of saturated & $2.61 \pm 0.41$ & $2.79 \pm 0.31$ \\
\hline
\end{tabular}

SFA - sum of saturated fatty acids, MUFA - sum of monounsaturated fatty acids, PUFA - sum of polyunsaturated fatty acids; P:S - ratio of PUFA to SFA; $n-6$ - sum of $n-6$ PUFA, n-3 - sum of n-3 PUFA, fatty acids n-6:n-3 ratio; AI atherogenic index, TI - thrombogenic index; nd - not detected; * $-P<0.05$

Feeding of bulls with the compound feed containing either rapeseed or linseed cake had no significant effect on the finish weight of bulls, carcass weights and dressing percentage, lean meat content and fatness grades being $\mathrm{O}$ and 2, respectively. M. longissimus dorsi analyses indicated that feeding bulls compound feeds with linseed cake resulted in higher total n-3 fatty acid content $(P<0.05)$ and more favourable ratio of n-6:n-3 fatty acids. 


\section{Conclusions}

1. Our study indicated that the content of linolenic acid (C18:3n-3) was 49.93\% higher in linseed cake than in rapeseed cake. Ratio of n-6:n-3 fatty acid in rapeseed cake was 2.75 and in linseed cake -0.25 . More favourable ratio in linseed cake was determined by a higher content of linolenic acid (C18:3n-3) in it.

2. Bull feeding with rapeseed, linseed cakes had no significant influence on the dressing percentage, leanness and fatness grades and morphological composition of carcasses.

3 . The content of linolenic acid $(\mathrm{C} 18: 3 n-3)$ in ground meat was significantly higher when bulls had been given linseed cake $(P<0.05)$, and, therefore, higher content of this acid in the feed had a positive effect on n-6:n-3 ratio. Musculus longissimus dorsi analyses indicated that feeding bulls compound feeds with linseed cake resulted in higher total n-3 fatty acids content $(P<$ 0.05 ) and more favourable ratio of $n-6: n-3$ fatty acids.

\section{Acknowledgements}

This research was funded by a grant (No. MT 11/30, LESPRO) provided by the Ministry of Agriculture of the Republic of Lithuania.

Received 10022015 Accepted 15062015

\section{References}

AOAC 1990. Official methods of analysis of the Association of the Official Analytical Chemists ( $18^{\text {th }}$ ed.). Arlington, USA

Bendikas P., Uchockis V., Tarvydas V., Švirmickas G. 2008. Bull's growth, carcass and meat quality by feeding of compound feed with rapeseed cake or meal. Livestock Science, 52: 60-70

Christopherson S. W., Glass R. L. 1969. Preparation of milk fat methyl esters by alcoholysis in an essentially nonalcoholic solution. Journal of Dairy Science, 52: 1289-1290 http://dx.doi.org/10.3168/jds.S0022-0302(69)86739-1

Commission Regulation (EU) No. 116/2010 of 9 February 2010 amending Regulation (EC) No. 1924/2006 of the European Parliament and of the Council with regard to the list of nutrition claims. Official Journal of European Union, $37 / 16$

Commission Regulation (EU) No. 376/2010 of 3 May 2010 amending Regulation (EC) No. 983/2009 on the authorisation and refusal of authorisation of certain health claims made on food and referring to the reduction of disease risk and to children's development and health. Official Journal of the European Union, 111/3

Dewhurst R. J., Scollan N. D., Lee M. R. F., Ougham H. J., Humphreys M. O. 2003. Forage feeding and management to increase the beneficial fatty acid content of ruminant products. Proceedings of the Nutrition Society, 62 (2): 329-336 http://dx.doi.org/10.1079/PNS2003241

Do Prado I. N., Moreira F. B., Matsushita M., de Souza N. E. 2003. Longissimus dorsi fatty acids composition of Bos indicus and Bos indicus $\times$ Bos taurus crossbred steers finished in pasture. Brazilian Archives of Biology and Technology, 46 (4): 601-608 http://dx.doi.org/10.1590/S1516-89132003000400015
Drouillard J. S., Seyfert M. A., Good E. J., Loe E. R., Depenbusch B., Daubert R. 2004. Flaxseed for finishing beef cattle: effects on animal performance, carcass quality and meat composition. Proceedings of the $60^{\text {th }}$ Flax Institute. Fargo, USA, p. 108-117

Ebrahimi M., Rajion M. A., Goh Y. M., Sazili A. Q., Schonewille J. T. 2013. Effect of linseed oil dietary supplementation on fatty acid composition and gene expression in adipose tissue of growing goats. BioMed Research International, article ID 194625: 1-11

Folch J., Less M., Sloane-Stanley G. H. 1957. A simple method for the isolation and purification of total lipids from animal tissues. Journal of Biological Chemistry, 226: 497-509

French P., Stanton C., Lawless F., O'Riordan E. G., Monahan F. J., Caffrey P. J., Moloney A. P. 2000. Fatty acid composition, including conjugated linoleic acid, of intramuscular fat from steers offered grazes grass, grass silage, or concentrate-based diets. Journal of Animal Science, 78: 2849-2855

Hegarty V. 1995. Lipids-fats, oils, and fat substitutes. Hegarty V. (ed.). Nutrition, food and the environment. Minnesota, USA, p. 171-195

Herdmann A., Nuernberg K., Martin J., Nuernberg G., Doran O. 2010. Effect of dietary fatty acids on expression of lipogenic enzymes and fatty acid profile in tissues of bulls. Animal. 4 (5): 755-762 http://dx.doi.org/10.1017/S1751731110000431

Jeroch H., Drocher W., Simon O. 1999. Ernährung landwirtschaftlicher Nutztiere. Stuttgart, Germany, 544 p. (in German)

Jiménez-Colmenero F., Carballo J., Confrades S. 2001. Healthier meat and meat products: their role as functional foods. Meat Science, 59: 5-13 http://dx.doi.org/10.1016/S0309-1740(01)00053-5

Kaldmäe H., Kass M., Kärt O., Oli A. 2006. Effect of temperature on the degradation of rapeseed cake protein. Veterinarija ir zootechnika, 36: 30-34

Komprda T., Dvořák R., Fialova M., Dvořák P. 2002. Effect of heat-treated rapeseed cake on fatty acid pattern in meat of fattened bulls. Czech Journal of Animal Science, 47 (2): 64-71

Marmer W. N., Maxwell R. J., Williams J. E. 1984. Effects of dietary regimen and tissue site on bovine fatty acid profiles. Journal of Animal Science, 59: 109-121

Nogalski Z., Pogorzelska-Przybylek P., Wronski M., WielgoszGroth Z., Purwin C., Sobczuk-Szul M., Mochol M. 2012. The effect of body conformation on meat performance in young bulls. Journal of Animal Production Advances, 2 (4): $182-188$

NuernbergK., DannenbergerD., NuernbergG.,EnderK., Voigt J., Scollan N. D., Wood J. D., Nute G. R., Richardson R. I. 2005. Effects of a grass-based and a concentrate feeding system on meat quality characteristics and fatty acid composition of longissimus muscle in different cattle breeds. Livestock Production Science, 94 (1-2): 137-147 http://dx.doi.org/10.1016/j.livprodsci.2004.11.036

Rule D. C., Wu W. H., Busboom J. R., Hinds F. C., Kercher C. J. 1989. Dietary canola seeds alter the fatty acid composition of bovine subcutaneous adipose tissue. Nutrition Reports International, 39: 781-786

Sailas B., Spener F. 2009. Conjugated linoleic acids as functional food: an insight into their health benefits. Nutrition Metabolism, 6: 1-13

Sanders T. S. B. 2003. High-versus low-fat diets in human diseases. Current Opinion in Clinical Nutrition and Metabolic Care. 6: 151-155 http://dx.doi.org/10.1097/00075197-200303000-00003

Sarwar M. F., Sarwar M. H., Sarwar M., Qadri N. A., Mogha S. 2013. The role of oilseeds nutrition in human health: a critical review. Journal of Cereals and Oilseeds, 4 (8): $97-100$

http://dx.doi.org/10.5897/JCO12.024 
Scollan N. D., Choi N. J., Kurt E., Fisher A. V., Enser M., Wood J. D. 2001. Manipulating acid composition of muscle and adipose tissue in beef cattle. British Journal of Nutrition, 85 (1): 115-124 http://dx.doi.org/10.1079/BJN2000223

Scollan N., Hocquette J. F., Nuernberg K., Dannenberger D., Richardson R. I., Moloney A. 2006. Innovations in beef production systems that enhance the nutritional and health value of beef lipids and their relationship with meat quality. Meat Science, 74 (1): 17-33 http://dx.doi.org/10.1016/j.meatsci.2006.05.002

Ulbricht T. L., Southgate D. A. 1991. Coronary disease seven dietary factors. Lancet, 338: 117-992 http://dx.doi.org/10.1016/0140-6736(91)91846-M

Vanhala M., Saltevo J., Soininen P., Kautiainen H., Kangas A. J., Ala-Korpela N., Mäntyselkä P. 2012. Serum omega-6 polyunsaturated fatty acids and the metabolic syndrome: a longitudinal population-based cohort study. American Journal of Epidemiology, 176 (3): 253-260 http://dx.doi.org/10.1093/aje/kwr504
Warren H. E., Scollan N. D., Enser M., Highes S. I., Richardson R. I., Wood J. D. 2008. Effect of breed and a concentrate or grass silage diet on beef quality in cattle of 3 ages. I. Animal performance, carcass quality and muscle fatty acid composition: a review. Meat Science, 78: $256-269$ http://dx.doi.org/10.1016/j.meatsci.2007.06.008

Wood J. D., Richardson R. I., Nute G. R., Fisher A. V., Campo M. M., Kasapidou E., Sheard P. R., Enser M. 2003. Effects of fatty acids on meat quality: a review. Meat Science, 66: 21-32 http://dx.doi.org/10.1016/S0309-1740(03)00022-6

Wood J. D., Enser M., Fisher A. V., Nute G. R., Sheard P. R., Richardson R. I., Huges S. I., Whittington F. M. 2008. Fat deposition, fatty acid composition and meat quality: a review. Meat Science, 78: 343-358 http://dx.doi.org/10.1016/j.meatsci.2007.07.019

ISSN 1392-3196 / e-ISSN 2335-8947

Zemdirbyste-Agriculture, vol. 102, No. 3 (2015), p. 319-324

DOI 10.13080/z-a.2015.102.041

\title{
Kombinuotụjų pašarų, papildytų rapsų ir sẻmenų išspaudomis, įtaka buliukų mèsos savybèms ir riebalų rūgščių sudėčiai
}

\author{
G. Baltrukonienè, V. Uchockis, G. J. Švirmickas \\ Lietuvos sveikatos mokslų universiteto Gyvulininkystės institutas
}

\section{Santrauka}

Tirti Lietuvos juodmargių veislès mèsai auginami 10-16 amžiaus buliukai. Buliukai ị analogines grupes buvo suskirstyti atsižvelgiant ị jų kilmę, amžių ir svorį. Tyrimo laikotarpiu abiejų grupių buliukai gavo vienodą kiekị kukurūzų siloso, dobilų, avižų bei žirnių mišinio siloso ir kombinuotųjų pašarų, skyrèsi tik kombinuotujjų pašarų sudètis. Tyrimo tikslas - ištirti galvijų prieauglio mitybai naudotus skirtingus kombinuotuosius pašarus su rapsų bei sẻmenų išspaudomis ir įvairiais kiekiais n-6 bei n-3 riebalų rūgščių, nustatyti jų santykị galvijų ilgiausio nugaros raumens (Musculus longissimus dorsi) mėsoje ir farše. Tyrimo metu nustatyta, kad linolo rūgšties (C18:3n-3) linų sėmenų išspaudose buvo 49,93 proc. daugiau nei rapsų išspaudose; riebalų rūgščių omega n-6 ir n-3 santykis rapsų išspaudose buvo 2,75, sėmenų išspaudose - 0,25. Geresnị n-6 ir n-3 santykị lèmė linų sėmenų išspaudose esantis didesnis kiekis linolo rūgšties (C18:3n-3). Buliukų šèrimas skirtingais kombinuotaisiais pašarais su rapsų bei sėmenų išspaudomis, riebalų rūgščių kiekiu ir n-6 bei n-3 santykiu neturèjo esminès įtakos jų svoriui prieš skerdimą, skerdenų svoriui ir išeigai, raumeningumui ir riebumo klasei. Abiejų grupių buliukų skerdenos buvo $\mathrm{O}$ raumeningumo ir 2 riebumo klasès. Tyrimo duomenimis, buliukus šeriant kombinuotaisiais pašarais su linų sėmenų išspaudomis, longissimus dorsi raumenyje buvo nustatytas 1,3 karto didesnis suminis n-3 riebalų rūgščių kiekis ir 1,5 karto mažesnis kiekybinis n-6:n-3 riebalų rūgščių santykis $(P<0,05)$ nei šeriant kombinuotaisiais pašarais su rapsų išspaudomis.

Reikšminiai žodžiai: galvijų skerdena, rapsų išspaudos, riebalų rūgštys, sėmenų išspaudos. 